\title{
原著
}

\section{唃蝕自然発症ラットにおける歯垢中の 触蝕原性細菌数の経月的推移*}

\author{
Cariogenic Bacterial Counts in Plaque of Rats \\ with Naturally Ocurring Dental Caries
}

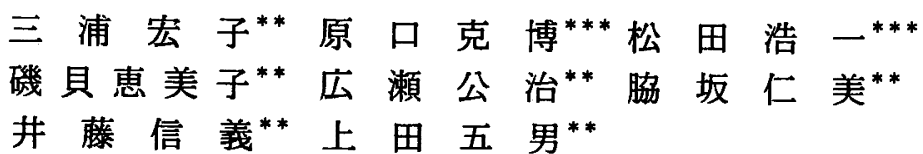
Hiroko MIURA**, Katsuhiro HARAGUCHI ${ }^{* * *}$, Koichi MATSUDA ${ }^{* * *}$, Emiko ISOGAI ${ }^{* *}$, Kimiharu HIROSE ${ }^{* *}$, Hitomi WAKIZAKA**, Nobuyoshi ITO ${ }^{* *}$ and Itsuo UEDA ${ }^{* *}$

Received April 15, 1991 ; accepted May 13, 1991

\begin{abstract}
The monthly changes in the counts of anaerobic bacteria, streptococci, and mutans streptococci in plaque of caries-susceptible rats (SDC) and control rats (CSC) were examined at 1, 2, 3, and 4 months. Carious lesions were also evaluated at each change by Keyes' method.

No changes in the bacterial counts were observed but there was a transient increase at 3 months, especially in mutans streptococci counts. Also, no significant difference in bacterial counts was found between SDC and CSC rats. However, SDC rats had significantly higher caries scores than CSC rats after 3 months $(\mathrm{p}<0.01)$. The monthly age of SDC rats when their caries scores were increased was consistent with the age when their bacterial counts were significantly increased.

These results suggested that the number of mutans streptococci contributed to dental caries in SDC rats, but that it was only a necessary conditions, but not a sufficient condition, for the occurrence of caries.
\end{abstract}

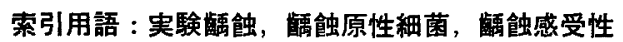

Koy words: Experimental dental caries, Cariogenic bacteria, Dental caries susceptibility

* 本論文の要旨は第36回口腔衛生学会総会（横須賀，昭和62年10月18日）で発表した。

** 東日本学園大学齿学部口腔衛生学講座（主任：上田五男教授）

** Department of Preventive Dentistry, School of Dentistry, Higashi-Nippon-Gakuen University (Chief: Prof. Itsuo UEDA)

****東日本学園大学歯学部歯科保存学第二講座（主任 : 松田浩一教授）

*** Department of Operative Dentistry and Endodontology, School of Dentistry, Higashi-NipponGakuen University (Chief: Prof. Koichi MATSUDA) 


\section{緒 言}

鹋触の発症要因には細菌, 食物, 宿主, 時閒等が挙げ られる11。このうち, 細菌要因については鹋蝕原性菌と してミュータンスレンサ球菌が注目されており2)，食物 要因についてはミュータンスレンサ球菌の最適基質であ るショ糖が䟼蝕の発症と密接に関わっていることが報告 されている゙)。宿主要因については，エナメル質表層の 組成や睡液の組成と分泌量が兓蝕と密接な関わりを有し

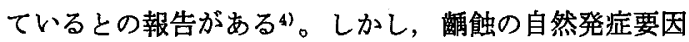
と環境要因との関わりについては，未だ明確ではない。

Miura et al. は, 龍蝕誘発能を有しない通常の市販固 型飼料のみで䀞蝕が自然発症するラット（SDC ラット） とその対照系ラット（CSC ラット）を開発し，䤍蝕発 症と宿主要因との関連性について報告した ${ }^{5)}$ 。原口らは,

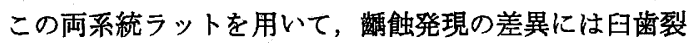
溝部の形態的因子が関与していることを報告してい

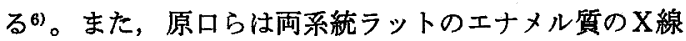
回折像より，SDC ラットの方がエナメル質の結晶性が 低いことを報告している7)。これらの研究より，両系統 間の㗕蝕発現の差異には，宿主要因が大きく関倸してい るむのと考えられる。しかしながら，Orland の実験8， が示すように, 㓻蝕の発症には雄蝕原性菌の伝播が必須 の条件であることから，両系統のラットの䀞蝕発現と酻 蝕原性細菌との関連性を調べることは必要である。

本研究は，能触原性細菌として最有力視されているミ ュータンスレンサ球菌を中心とした，数種の歯垢中の細

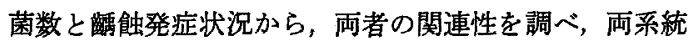
間の满強発症の差異を検討する一助とするものである。

\section{材料および方法}

実験動物は, 東日本学園大学実験動物センターにて, inbred で継代繁殖中の㪤蝕感受性ラット（SDC ラッ ト）とその対照系ラット（CSC ラット）を使用した。 ラットに解蝕を誘発させるには, 通常, ミュータンスレ ンサ球菌の接種やショ糖の摂取等が不可欠とされるが, SDC ラットは市販固型飼料のみで譪強が発症する自然 発症ラットである。

飼料は，市販の固型飼料として沉用されているオリエ ンタル酵母社製の MF 飼料を用いた。なお，飼料およ び飲料水は自由に攝取させ，飼育は conventional な環 境で行った。

SDC ラットと CSC ラットは, 生後1 か月, 2 か月, 3 か月，4 か月の各時点で，それぞれ10匹（占 5 匹，우
5 匹）ずつ屠殺し，䀞蝕発症状況の評価と細菌学的実験 に供した。歯牙標本の調製法および兓能発現頻度の評価 は, Keyes の方法9!従って行った。

各月齢のラットの歯牙表面に付着したプラークを採取 し，以下の要領で細菌培盖を行った。プラークの採取 は, ラットをクロロホルムにて屠殺後，分離した上下䫑 曰歯部より滅菌綿棒で Swab する方法で行った。採取 したプラークの重量を電子天科で，綿棒ごと測定した 後, 直ちに嫌気ボックス内に移し，検体を嫌気条件 (80 $\%, \mathrm{~N}_{2}, 10 \% \mathrm{H}_{2}, 10 \% \mathrm{CO}_{2}$ ) 下に保った。歯垢が付着 した滅菌綿棒を GAM broth (日水製薬社製) $10 \mathrm{~m} l$ 中 でよく分散させ，連続階段希釈を行った。非選択培地と して，馬脱線維血液を $5 \%$ 添加した BL 培地（日水製 薬社製)，レンサ球菌の選択培地として，Mitis Salivarius 培地 (Difco Laboratories, MS 培地), およびミュ ータンスレンサ球菌の選択培地として Gold の MSB 培地 ${ }^{10}$ を用いた。BL 培地は嫌気条件下で 2 日間培養し， MS 培地と MSB 培地は嫌気条件下で 1 日培養し, さ らに好気条件下で 1 日培䖯した。培養後, 総嫌気性菌 数, 総レンサ球菌数, およびミュータンスレンサ球菌数 を計測し，それぞれプラーク $1 \mathrm{mg}$ あたりの細菌数を求 めた。

なお，両系統間の有意差の検定には $\mathrm{t}$ 検定を用いた。

\section{結果}

\section{1. 触強発現状況について}

両系統ラットの瞒蝕指数の経月的推移を Fig. 1 に示 した。生後 1 か月の時点では両系統とも甄強の発現は殆 ど認められなかったが, 生後 2 か月の時点で, 㼐蝕の発 現が認められた。2 か月での唃蝕発現数は, 両系統間で 有意な差はなかったが，SDC ラットの方が高かった。 生後 3 か月になると, SDC ラットの発現頻度が著しく 増加し，CSC ラットに較べて有意に高い值を示した（p $<0.01)$ 。生後 4 か月では, SDC ラットの鹋蝕がさらに 進行して, 両系統間での差異は一層顕著となった。

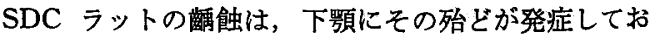
り，特に下顎第 1 大臼歯と第 2 大臼菊の裂溝部に好発し ていた。

なお，鹋蝕発症状況に関する性差は，両系統ラットと も認められなかった。

2. プラーク中の細菌数について

両系統のプラーク $1 \mathrm{mg}$ 当たりの総嫌気性菌数, 総レ ンサ球菌数, およびミュータンスレンサ球菌数の経月的 推移について, その平均値と標準偏差を Fig. 2 に示し 


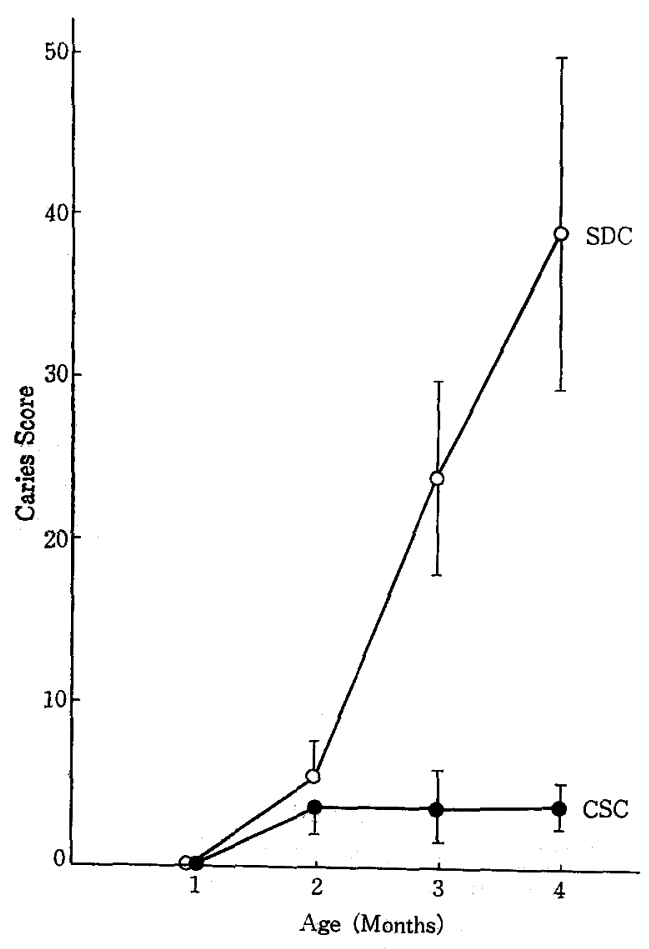

Fig. 1 Comparison of change in caries scores between SDC and CSC rats (mean \pm S. E.) ( $O:$ SDC rat, $\bullet:$ CSC rat)

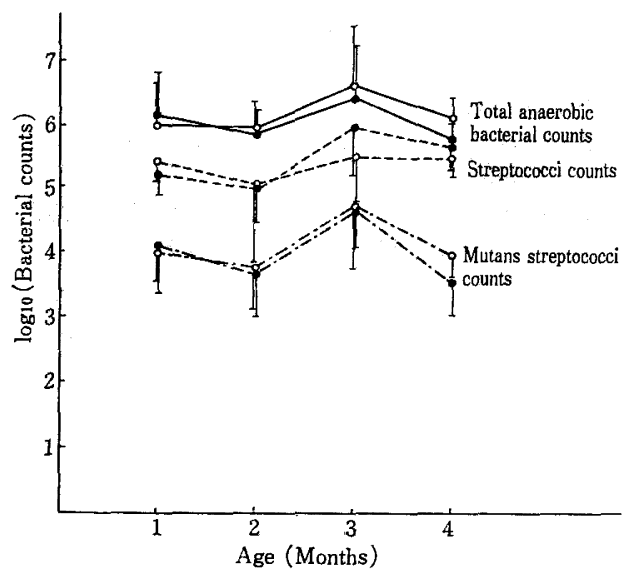

Fig. 2 Change in the number of total anaerobic bacteria, streptococci, and mutans streptococci in plaque between SDC and CSC rats (mean \pm S.D.) (-: total anaerobic bacteria, - - : streptococci, -..-: mutans streptococci; $O$ : SDC rat, $\bullet:$ CSC rat)
た。菌数は、いずれもほぼ同様な経月的変化を示してい る。すなわち, 生後 2 か月までは菌数の変動が少なく, 3か月に招いて増加し，4 月月では再び減少している。 特に，ミュータンスレンサ球菌で，この傾向は影著であ り, 生後 2 か月から 3 か月にかけて有意に細菌数が増加 した（p<0.05）。ただし，総レンサ球菌数では個体間の バラツキが大きく，2 2 月から 3 か月にかけての增加 は，統計的には有意ではなかった。また，両系統間にお ける差異についても，今回調べた範囲では有意な差は認 められなかった。なお, 両系統ともプラーク中の細菌数 に関して性差は認められなかった。

\section{考察}

前報同様，市販固型飼料のみで飼育した二系統のラッ トのらち, SDC ラットでは, 旅触が極めて高頻度に発 症した。一方, その対照系である CSC ラットでは, 撂蝕は全観察期間を通して低頻度しか発症しなかった。 両系統の酮蝕発症状況の差異は, 生後 2 只加ら 3 加 にかけて現われ始め, 生後 4 か月になると一層顕著にな つた。つまり，SDC ラットは生後 2 か月を経過した段 階で，何らかの因子により唃蝕感受性が増大寸るものと 考えられる。また，その後も甄蝕の進行を助長する因子 が作用していることが考えられる。一般に，ラットの成 長は10〜15週で成年期に達するといわれており ${ }^{11) ， ま た ~}$ 歯質の成熟 む歯牙萌出後 $2 \sim 3$ 週間でほぼ達成されると いかれている12)。したがって，固型飼料を用いた SDC ラットのこの時期における鹋触の発症は，七トの場合の 一般的な要因に加えて, 生得的な要因も考慮しなければ ならないものと考えられる。

そこで, ラットプラーク中の総レンサ球菌数およびミ ュータンスレンサ球菌数の月齢変化をみると，いずれも 生後 3 か月において, それらの増加が認められる。総嫌 気性細菌数においても, 同様な増加傾向が認められる が, 他の菌数に較べて顕著ではない。このように菌種に より若干の相違は認められるが，ラットでは茅蝕原性の 有無によらず, 生後 2 か月〜 3か月で歯垢中の細菌の増 殖が起こり易いことを示している。その要因について は, 現在のところ不明であるが，全身的な代謝機能の一 部との関連性を追究する必要があると考えられる。

ラットの菌数が増加する月龄と SDC ラットの触蝕発 症月齢とが極めてょく一致しており，このことは, 䀞触 誘発要因として細菌因子, 特にミニータンスレンサ球菌 の役割を強く支持するものである。しかし，ミュータン スレンサ球菌が歯垢中で増殖を開始してもなお，CSC 
ラットにおいて，嗝蝕の発症が少ないことは，ミュータ ンスレンサ球菌が䔯蝕発症の必要条件であっても，必ず しも十分条件ではないことを意味している。この点につ いては, 両系統のミュータンスレンサ球菌の酸産生能に ついても検討する必要がある。

ラットの䟼蝕好発部位は, 裂溝底部である。この部分 は低石灰火の筍所であり，酸によって侵されやすい18)。 したがって，ひとたび裂溝部で酸が産生されると，この 部位のエナメル質の薄さと相まって, 脱灰はかなり急速 に進み，比較的早期に象牙質まで到達するむのと考えら れる。SDC ラットは CSC ラットに比較して, 裂溝部 が哚く鋭角な形態を有するので, 特にプラークの沈着が 生じやすく, その結果, 蔍蝕が発症しやすい環境になる ことが考えられる。

\section{結 論}

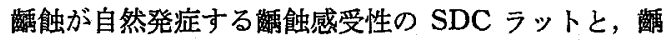
蝕抵抗性である CSC ラットのプラーク中の総嫌気性菌 数, 総レンサ球菌数, およびミュータンスレンサ球菌数 の経月的推移を調べた結果, 菌数の月齢変化では両系統 間に有意差が認められなかった。しかし，ラットの菌数 が増加する月齢と SDC ラットの酮蝕発症月齢とが, 極 めてよくー致していた。

\section{文献}

1) Nikiforuk, G.: Understanding dental caries 1 Etiology and mechanisms Basic and clinical aspects, Karger, Basel, 1985, p. 79.

2）須賀昭一：四説触蝕学, 医歯薬出版, 東京, 1990, p. 107.

3）須賀昭一：図説触蝕学, 医歯薬出版, 東京, 1990, p. 120.

4) Thylstrup, A. and Fejerskov, O.: Text- book of cariology, Munksgaard, Copenhagen, 1986, p. 181.

5) Miura, H., Ueda, I., Wakizaka, H., Isogai, H. and Ito, N.: Studies on caries occurrence in rats with naturally occurring dental caries, Jpn. J. Oral Biol., 30 ; 539-544, 1988.

6）原口克博，三浦宏子，渡辺敏彦，荆木裕司， 井藤信義, 松田浩一: 䊈蝕自然発症ラットの研 究 第 1 報 歯の形態と寸法, 日歯保誌, 31； 1026-1032, 1988.

7）原口克博, 三浦宏子, 制木裕司, 松田浩一, 上田五男, 井藤信義, 森脇豊: 麇蝕自然発症 ラットの研究 第 2 報 X線回折法によるエナ メル質の結晶の評価， 日歯保誌， 33 (秋期特別 号)；132，1990.

8) Orland, F. J., Blayney, J. R., Harrison, R. W., Reyniers, J. A., Trexler, P. C., Wag. ner, M., Gordon, H. A. and Luckey, T. D.: Use of the germfree animal technic in the study of experimental dental caries, J. Dent. Res., 33 ; 147-174, 1954.

9) Keyes, P. H. : Dental caries in the molar teeth of rats. II A method for' diagnosing and scoring several types of lesions simultaneously, J. Dent. Res., 37 ; 1077-1087, 1958.

10) Gold, O. G., Jordan, H. V., van Houte, J.: A selective medium for Streptococcus mutans, Archs. oral Biol., 18 ; 1357-1364, 1973.

11) 石橋正彦, 高橋寿太郎, 菅原七郎, 安田泰久: 実験動物学ラット, 講談社, 東京, 1984, p. 111.

12) Navia, J. M. : Animal models in dental research, The University of Alabama Press, Alabama, 1977, p. 249.

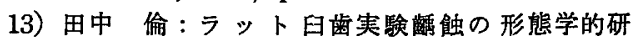
究，鶴見蔽学，15；183-199，1989. 